\title{
IbM KELOMPOK PEMBUAT BATU BATA DI KELURAHAN GUNTUNG MANGGIS, KECAMATAN LANDASAN ULIN, KOTA BANJARBARU
}

\author{
Dahlena Ariyani'), Dwi Rasy Mujiyanti' ${ }^{2}$, Maria Dewi Astuti ${ }^{3)}$, dan Rodiansono ${ }^{4)}$ \\ ${ }^{122) 34}$ Program Studi Kimia, Fakultas Matematika Dan Ilmu Pengetahuan Alam, Universitas Lambung \\ Mangkurat \\ Jl. A. Yani km 36 Banjarbaru, Kalimantan Selatan 70721 \\ ${ }^{1)}$ Korespondensi Email : drmujiyanti@unlam.ac.id
}

\begin{abstract}
ABSTRAK
Program IbM ini bertujuan untuk meningkatkan pendapatan pembuat batu bata di Kelurahan Guntung Manggis. Proses pembuatan batu bata yang lebih ramah lingkungan dan ekonomis dengan komposisi pemanfaatan silika, salah satunya dari abu sekam padi. Batu bata tanpa proses pembakaran yang memiliki kualitas tinggi tidak kalah di pasaran dengan batu bata konvesional sehingga akan menghasilkan keuntungan yang lebih baik. Kegiatan IbM yang dilaksanakan melibatkan kelompok pembuat batu bata di Kelurahan Guntung Manggis terhadap dua mitra Kelompok pembuat batu bata Kuranji dan Kelompok pembuat batu bata Sei Salak. Kegiatan yang dilaksanakan terhadap Mitra I dan Mitra II berupa pelatihan pembuatan batu bata tanpa pembakaran yaitu dengan penambahan silika dalam proses produksi batu bata. Proses pembuatan dengan metode tersebut akan menjadikan suatu pengetahuan yang baru dan dapat memanfaatkan serta mengurangi limbah sekam padi yang ada. Luaran kegiatan ini berupa teknologi Green Construction dimana batu bata silika dibuat dari tanah liat dan limbah sekam padi tanpa pembakaran dan pemahaman manajemen usaha sehingga pendapatan yang diperoleh meningkat. Berdasarkan analisis ekonomi bata konvensional dan bata tanpa pembakaran dengan skala produksi 100 buah bata, dapat dikalkulasikan terjadinya pengurangan biaya produksi sehingga menjadikan pengurangan harga jual bata dibandingkan dengan bata konvensional dengan nilai pengurangan berkisar Rp. 63,5 per bata.
\end{abstract}

\section{PENDAHULUAN}

Kelompok Pembuat Batu Bata yang terletak di Guntung Manggis merupakan sekumpulan pekerja yang berwirausaha dalam memproduksi batu bata yang terbuat dari tanah liat melalui proses pembakaran. Dalam wilayah Guntung Manggis, kelompok pembuat batu bata berada pada wilayah Kuranji dan Sei Salak yang tersebar hampir merata. Sebagian besar kelompok pembuat batu bata lebih menekankan produksi batu bata tanah liat dengan pembakaran secara konvensional. Pembakaran tersebut menghasilkan gas karbondioksida dan dapat mengganggu pencemaran udara di lingkungan sekitar.

Kajian pemanfaatan limbah dalam mencapai green effect semakin meningkat, salah satunya dalam bahan bangunan. Hal ini didasari oleh pembangunan fisik yang terus bertambah seiring dengan pemerataan pembangunan di Indonesia secara menyeluruh. Perkembangan ilmu pengetahuan dan teknologi dalam hal material bangunan juga terus berkembang, khususnya ke arah konsep pembangunan hijau (green construction). Oleh sebab itu, limbah yang selama ini mengganggu lingkungan dan masyarakat sekitar, dapat dimanfaatkan agar tidak hanya sebagai bahan sisa atau bahan buangan.

Sekam padi merupakan produk samping yang melimpah dari hasil penggilingan padi. Sekam padi bila dibakar akan menghasilkan sekitar 20\% abu sekam. Pemanfaatan sekam padi secara komersil masih 
relatif kecil. Hal ini karena sifat yang dimilikinya antara lain kasar, nilai gizi rendah, kepadatan yang juga rendah, serta kandungan abu yang cukup tinggi (Houston, 1972). Abu tersebut mengandung silika $\left(\mathrm{SiO}_{2}\right)$ antara 90 95\%, dengan tingkat porositas yang tinggi, ringan dan permukaan eksternal yang luas sangat cocok untuk bahan campuran material bangunan seperti batu bata. Berdasarkan hal tersebut maka pemanfaatan limbah abu sekam padi untuk pembuatan batu bata tanpa pembakaran perlu dikembangkan.

Berdasarkan diskusi antara tim pengusul pengabdian dengan mitra (Kelompok Batu Bata Kuranji dan Kelompok Batu Bata Sei Salak) permasalahan yang mereka hadapi adalah bahan bakar yang semakin susah didapatkan dan proses pembakaran yang menyebabkan pencemaran lingkungan. Oleh karena itu diperlukan proses pembuatan batu bata yang lebih ramah lingkungan dan ekonomis dengan komposisi pemanfaatan silika dari sumber silika, salah satunya dari abu sekam padi.

\section{METODE PELAKSANAAN}

Metode pelaksanaan pengabdian kepada masyarakat dilakukan dalam beberapa tahap. Rangkaian kegiatan yang dilakukan selama dua bulan tersebut adalah persiapan, pembahasan materi kegiatan, penyusunan alat dan bahan, survei lapangan, diskusi hasil survei lapangan, pembahasan pembuatan mesin cetak dan pengujian hasil uji tekan sebelum sosialisasi

Pada penerapan awal akan dibuat bata contoh dengan variasi lamanya waktu sampel fermentasi dengan komposisi campuran bahan perekat yang sama dimana nantinya akan dicari mana sampel yang kualitasnya paling tinggi dan yang paling rendah. Sampel yang akan dibuat dengan komposisi campuran bahan perekat dengan variasi sebagai berikut:

Tabel 1. Komposisi pembuatan batu bata silikat

\begin{tabular}{|c|c|c|c|}
\hline \multirow[t]{2}{*}{ Campuran } & \multirow[t]{2}{*}{$\begin{array}{c}\text { Tanah } \\
\text { Liat }\end{array}$} & \multicolumn{2}{|c|}{$\begin{array}{c}\text { Campuran Bahan } \\
\text { Perekat }\end{array}$} \\
\hline & & $\begin{array}{c}\text { Abu } \\
\text { Sekam } \\
\text { Padi }\end{array}$ & Semen \\
\hline $\begin{array}{l}\text { Bata } \\
\text { (fermentasi } \\
\mathrm{H}+0 \text { ) }\end{array}$ & $70 \%$ & $20 \%$ & $10 \%$ \\
\hline $\begin{array}{l}\text { Bata } \\
\text { (fermentasi } \\
\mathrm{H}+1)\end{array}$ & $70 \%$ & $20 \%$ & $10 \%$ \\
\hline $\begin{array}{l}\text { Bata } \\
(\text { fermentasi } \\
\mathrm{H}+3)\end{array}$ & $70 \%$ & $20 \%$ & $10 \%$ \\
\hline
\end{tabular}

Ket : Setiap sampel campuran dibuat masingmasing sebanyak 20 buah batu bata

Untuk membuat sampel batu bata tanpa pembakaran diperlukan bahan-bahan yang digunakan dan dalam penelitian ini sesuai dengan pembuatan batu bata home industri. Sebelum membuat batu bata tanpa pembakaran perlu persiapan bahan campuran yang digunakan yaitu:

1. Tanah yang digunakan dibersihkan dari segala kotoran berupa batu, daun dan sampah lainnya.

2. Abu sekam padi yang diperoleh dari industri batu bata masih berukuran besar sehingga tidak dapat disaring langsung dengan menggunakan saringan nomor 200. Abu sekam padi tersebut perlu ditumbuk terlebih dahulu sehingga berukuran sangat halus, kemudian menyaring dengan menggunakan saringan nomor 200.

3. Semen portland masih dalam keadaan utuh. 
4. Air yang digunakan berupa air bersih dari PDAM atau berasal dari sumber air bersih lainnya.

Proses pencampuran dilakukan dengan urutan tanah liat, , abu sekam padi dan semen yang diaduk samapi merata. Kemudian ditambahi Air (sedikit demi sedikit sampai adonan cukup liat). Kemudian dimasukkan ke kantong plastik (selama 1-3 hari) dan dilumatkan kembali sampai adonan benarbenar menyatu. Adonan kemudian siap untuk dicetak dengan cetakan kayu. Setelah pencetakan selesai dilakukan, melanjutkan dengan proses pengeringan 2-3 hari, baru kemudian melakukan proses mendiamkan batu bata selama 14 hari pada suhu lembab dan terhindar dari hujan dan panas matahari secara langsung.

Analisis Usaha. Suatu kegiatan usaha tani pada akhirnya akan dinilai dari biaya produksi dan penerimaan. Selisih antara penerimaan dan biaya produksi (pengeluaran) merupakan pendapatan. Biaya produksi atau pengeluaran adalah semua faktor produksi yang digunakan baik dalam bentuk benda maupun jasa selama proses produksi berlangsung. Pengeluaran juga mencakup penurunan investasi usaha batu bata. Pendapatan usaha batu bata dapat dihitung dengan mengurangi nilai total output (penerimaan) dengan nilai total input (biaya). Dalam bentuk matematis ditulis sebagai berikut :

$$
\mathrm{I}=\mathrm{TR}-\mathrm{TC}
$$

TR (Total Reveneu) adalah produk total (Yi) dikalikan harga (Pyi), dan TC (total Cost) adalah banyaknya input (Xi) dikalikan harga (Pxi).

Keberhasilan suatu usaha tani dapat dilihat dari tingkat keuntungan yang telah dicapai. Metode yang dapat digunakan untuk mengukur tingkat keuntungan usaha batu bata sekaligus membandingkan tingkat efisiensi adalah dengan nilai $\mathrm{R} / \mathrm{C}$ ratio atau RCR (Revenue Cost Ratio). RCR merupakan perbandingan antara Total Revenue (TR) dengan Total Cost (TC), yang secara matematis dirumuskan sebagai berikut:

$\begin{array}{ccc}\mathrm{RCR}= & \mathrm{TR} / \mathrm{TC} \\ \text { Usaha } & \text { tani } & \text { dapat dikatakan }\end{array}$ menguntungkan bila rasio antara penerimaan total dengan biaya total lebih besar dari 1. Ini berarti setiap pengeluaran biaya atau rupiah sebesar satu satuan akan memberikan penerimaan lebih dari satu satuan penerimaan atau rupiah. Bila $\mathrm{RCR}=1$ berarti usaha tani dalam keadaan impas. Bila RCR $<1$, berarti usaha batu bata mengalami kerugian, dan bila RCR $>1$ berarti usaha batu bata mengalami keuntungan.

Setiap aktivitas pelatihan akan didampingi oleh Tim Pengabdi dan dibantu oleh 2 mahasiswa. Tugas mahasiswa adalah membantu proses pelatihan dan melakukan pendampingan selama proses pengabdian berjalan sampai mitra bisa mandiri. Selain tim pengusul (pelaksana) dan mitra ada berbagai pihak yang terkait dan mendukung dalam kegiatan ini yaitu : Dikti, Unlam (LPM), Tim Pengusul (pelaksana), khalayak sasaran/mitra, dan Lembaga Desa.

Peran para pihak tersebut adalah sebagai berikut : Kemdikbud-Dikti ; penyandang dana dan pemantau, LPPM Unlam : pembina kegiatan Pengabdian pada masyarakat di tingkat universitas, Tenaga pengabdi; Pengelola kegiatan serta pendamping kelompok masyarakat (khalayak sasaran/mitra) dan Khalayak sasaran (Kelompok Pengusaha Bata Konvensional Kuranji dan Sei Salak) 


\section{HASIL KEGIATAN}

Kegiatan IbM ini dilakukan dalam beberapa tahap. Secara keseluruhan, kerja sama yang dilakukan oleh tim pelaksana dengan mitra adalah dalam bidang penyuluhan, pendampingan peroduksi, pelatihan produksi, dan pelatihan manajemen usaha.

Secara khusus, kegiatan penyuluhan dan pelatihan dalam pengabdian ini sudah dilaksanakan selama empat bulan, terhitung dari tanggal 24 Juli - 24 Nopember 2017. Rangkaian kegiatan yang dilakukan selama empat bulan tersebut adalah persiapan, pembahasan materi kegiatan, penyusunan alat dan bahan, survei lapangan, diskusi hasil survei lapangan, pembahasan pembuatan mesin cetak dan pengujian hasil uji tekan sebelum sosialisasi

\section{Tahapan Kegiatan Awal}

Tahapan awal dalam program pengabdian kepada masyarakat adalah kunjungan ke tempat pengusaha batu bata melalui perijinan lewat Ketua RT (RT.033 RW 006, Kelurahan Guntung Manggis) setempat. $\mathrm{Hal}$ ini bertujuan untuk bisa menjadikan hasil pertemuan yang efektif dan wadah diskusi yang baik dalam program kerja pembuatan bata bata tanpa pembakaran dan mendapatkan respon yang baik.

Setelah proses perijinan, kemudian melakukan pembuatan batubata contoh dengan metode yang digunakan dalam penelitian ini adalah metode studi literatur dan metode eksperimen dengan cara membuat bata merah tanpa bakar yang dilakukan dengan cara rekayasa serta inovasi material pembentuk selain tanah juga ditambahkan semen, dan abu sekam padi dan dicetak persegi panjang dengan ukuran standard yaitu ukuran panjang 190 , lebar 90, dan tebal $50 \mathrm{~mm}$. Kualitas yang didapat akan diuji apakah memenuhi persyaratan yang dibuktikan dengan uji fisik pada bata

Dalam pembuatan bata contoh, dibuat variasi sampel berdasarkan perbedaan waktu fermentasi dan dicari mana sampel yang paling tinggi berkualitas dan yang paling rendah kualitasnya khususnya dalam nilai kuat tekan dan rendam air (data di lampiran). Proses pencampuran dilakukan dengan urutan tanah liat, abu sekam padi dan semen yang diaduk sampai merata. Kemudian ditambahi air (sedikit demi sedikit sampai adonan cukup liat). Kemudian dimasukkan ke kantong plastik (selama 1-3 hari) dan dilumatkan kembali sampai adonan benar-benar menyatu. Adonan kemudian siap untuk dicetak dengan cetakan kayu. Setelah pencetakan selesai dilakukan, melanjutkan dengan proses pengeringan 2-3 hari, baru kemudian melakukan proses mendiamkan batu bata selama 14 hari pada suhu lembab dan terhindar dari hujan dan panas matahari secara langsung.

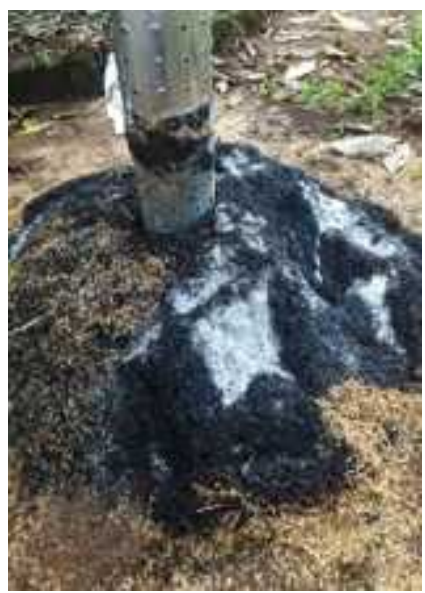

Gambar 1. Proses sekam padi menjadi abu sekam padi

Setelah pembuatan bata contoh, kemudian dilakukan tahap sosialisasi dengan pengusaha batu bata wilayah Kuranji-Sei Salak untuk bisa sebagai wadah pengetahuan secara jelas melalui presentasi, poster program kerja, dan diskusi bersama dalam pemahaman lebih 
mendalam kegiatan pengabdian ini. Kegiatan sosialisasi awal dengan pengusaha dan tim pengabdi beserta mahasiswa sebagai pendamping praktek dilaksanakan di kediaman bapak RT setempat, bapak Badrun. Beberapa gambaran sosisalisasi dapat dilihat di bawah ini

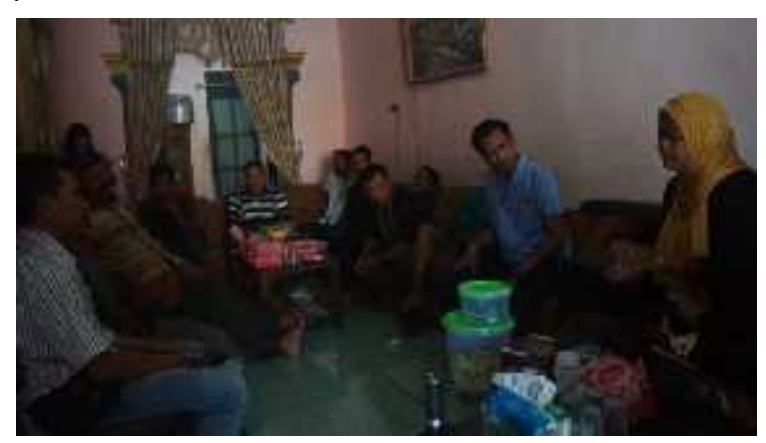

Gambar 2. Diskusi dalam prosedur pembuatan bata

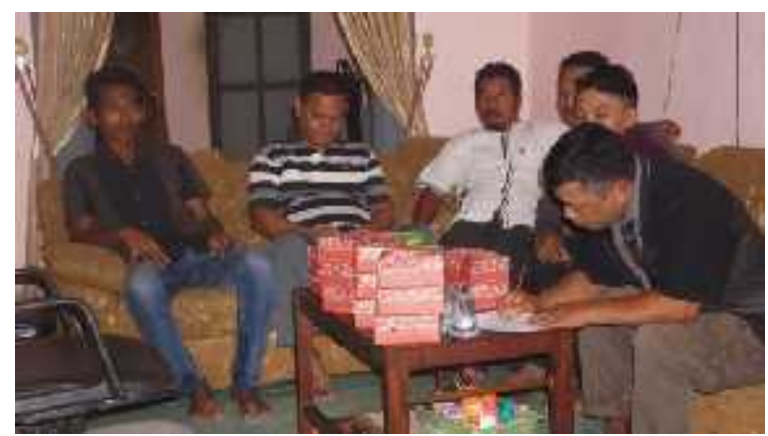

Gambar 3. Koordinasi persiapan pertemuan awal

Kegiatan sosialisasi mendapatkan respon yang secara umum baik. Hal ini mengingat dalam pembuatan batu bata tanpa bakar menggunakan penghilangan prosedur pembakaran. Meskipun ada sedikit kekhawatiran karena produksi bata ini masih belum umum terjual (familiar). Selain itu, uji strandar yang mereka tekankan lebih pada uji resapan air, karena umumnnya uji tersebut juga menjadi kontrol dalam proses penjualan bata. Dalam sosialisasi awal, kita sudah bisa memberikan gambaran uji tekan pada bata konvensional kisaran rata-rata $47,73 \mathrm{~kg} / \mathrm{cm}^{2}$ sedangkan pada bata tanpa pembakaran, telah dihasilkan antara $42,70-52,73 \mathrm{~kg} / \mathrm{cm}^{2}$. Secara keseluruhan komposisi material pada bata mengalami peningkatan baik pada uji tekan dibandingkan pada bata dengan pembakaran. Dalam hal ini, penambahan material semen dan abu sekam padi menjadikan kualitas bata dari lemah dan cepat patah menjadi kuat dan tak mudah patah dan memenuhi persyaratan standar uji tekan yaitu min $20 \mathrm{~kg} / \mathrm{cm}^{2}$ menurut SNI dan ASTM.

\section{Tahapan Penerapan Produksi}

Tahap koordinasi dan sosialisasi selesai kemudian dilakukan tahapan penerapan produksi batu bata tanpa bakar. Penerapan produksi sampai dengan Agustus telah dilaksanakan sebanyak 2 kali . Berikut gambaran kegiatannya :

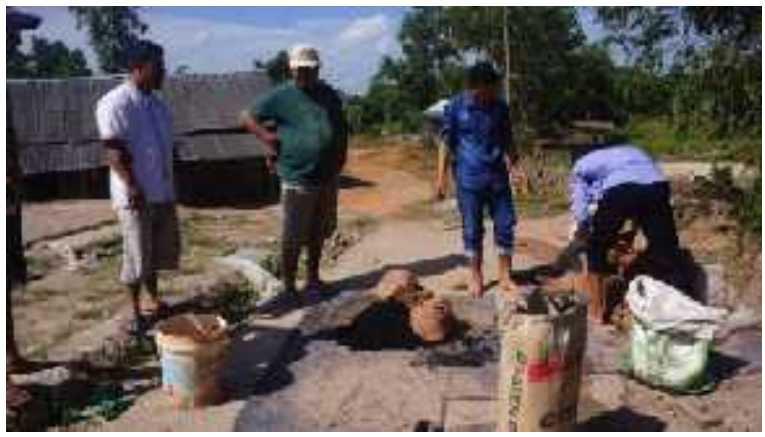

Gambar 4. Persiapan pembuatan campuran komposisi bata tanpa bakar

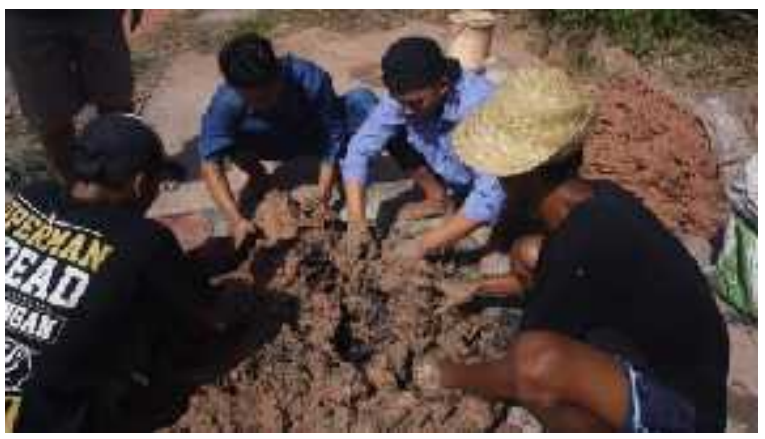

Gambar 5. Pencampuran komposisi secara rata (sebelum cetak) 


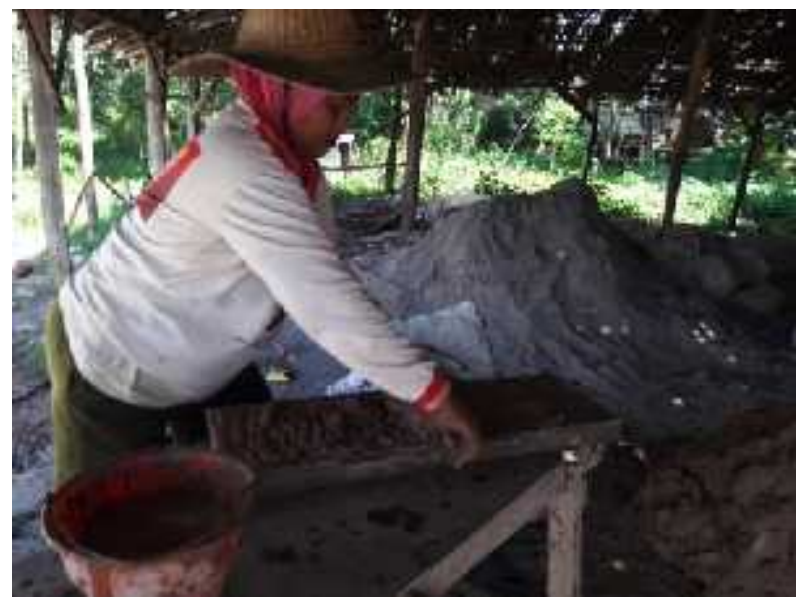

Gambar 6. Pencetakan bata

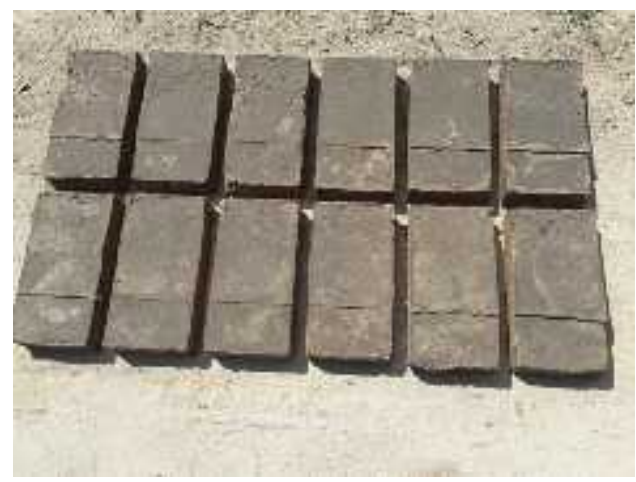

Gambar 7. Proses penjemuran bata

Secara umum, proses penerapan produksi berlangsung baik baik dalam skala pembuatan bahan awal sampai dengan pencetakannya. Respon pengusaha bata cukup baik mengingat bata tanpa pakar sangatlah mengurangi pembiayaan dari penggunaan bahan bakar kayu dan upah pekerja dalam proses pembakaran bata. Hal ini sangat menjadikan peluang baik, khususnya tim pengabdi dan umumnya para mitra dikarenakan tujuan untuk bisa menjadikan hasil pengabdian dapat berguna.

Dalam tahap lanjutan, dilakukan proses penerapan manajemen usaha dalam hasil tindak lanjut pemasaran batu bata tanpa pembakaran. Hal ini mengingat, produk bata non pembakaran masih sangat minim dan perlu adanya dukungan pemasaran yang efektif sehingga dapat tersosialisasikan dengan baik. Berikut analisis perekonomian dan perbandingan dalam pembuatan bata tanpa pembakaran dengan bata konvensional (bata dengan pembakaran).

Tabel 2. Analisis ekonomi bata konvensional dan bata tanpa pembakaran dengan skala produksi 100 buah bata (skala produksi kecil)

\begin{tabular}{|c|c|c|c|c|}
\hline \multirow[t]{2}{*}{$\begin{array}{c}\mathrm{N} \\
\mathrm{O}\end{array}$} & \multicolumn{2}{|c|}{$\begin{array}{c}\text { Bata dengan } \\
\text { Bakar }\end{array}$} & \multicolumn{2}{|c|}{ Bata tanpa Bakar } \\
\hline & $\begin{array}{c}\text { Kompo } \\
\text { nen }\end{array}$ & $\begin{array}{c}\text { Biaya } \\
\text { (Rp) }\end{array}$ & $\begin{array}{c}\text { Kompo } \\
\text { nen }\end{array}$ & $\begin{array}{l}\text { Biaya } \\
\text { (Rp) }\end{array}$ \\
\hline 1 & Tanah & $\begin{array}{c}270 / b \\
\text { ata }\end{array}$ & $\begin{array}{c}\text { Tanah } \\
\text { Liat }\end{array}$ & $\begin{array}{c}270 / \mathrm{b} \\
\text { ata }\end{array}$ \\
\hline 2 & $\begin{array}{l}\text { Kayu } \\
\text { Bakar }\end{array}$ & $\begin{array}{c}170 / \mathrm{b} \\
\text { ata }\end{array}$ & $\begin{array}{c}\text { Abu } \\
\text { Sekam }\end{array}$ & $\begin{array}{c}150 / \mathrm{b} \\
\text { ata }\end{array}$ \\
\hline 3 & $\begin{array}{l}\text { Upah } \\
\text { Kerja }\end{array}$ & $\begin{array}{c}250 / \mathrm{b} \\
\text { ata }\end{array}$ & Semen & $\begin{array}{c}24 / \text { bat } \\
\text { a }\end{array}$ \\
\hline 4 & & & Upah & $\begin{array}{c}150 / \mathrm{b} \\
\text { ata }\end{array}$ \\
\hline 5 & & & Pasir & $\begin{array}{c}12,5 / b \\
\text { ata }\end{array}$ \\
\hline & Total & $\begin{array}{c}670 / b \\
\text { ata }\end{array}$ & Total & 606,5 \\
\hline
\end{tabular}

Berdasarkan Tabel 2, dapat dikalkulasikan terjadinya pengurangan biaya produksi sehingga menjadikan pengurangan harga jual bata dibandingkan dengan bata konvensional dengan nilai pengurangan berkisar Rp. 63,5 per bata. Keuntungan yang tidak terlalu signifikan dikarenakan ada prosedur upah kerja yang masih sangat diperlukan mengingat ada perlakuan pembuatan adonan menjadi lebih homogen.

\section{KESIMPULAN}

Kesimpulan yang dapat diambil dari kegiatan PKM Kelompok Pembuat Batu Bata di Kelurahan Guntung Manggis, Kecamatan Landasan Ulin, Kabupaten Banjarbaru sebagai berikut : 
1. Antusiasnya warga dalam pelatihan pembuatan batu bata tanpa pembakaran sebagai wacana pembaruan dalam Green Production sehingga menjadikan produk Green Contruction

2. Proses pembuatan bata tanpa bakar dapat memecahkan masalah mengenai lamanya waktu dan proses pembuatan dengan jalan melakukan inovasi material dengan penambahan bahan semen dan abu sekam padi dengan waktu proses selama 3 hari.

3. Proses pembuatan bata tanpa bakar dapat mengurangi polusi yang ditimbulkan akibat proses pembakaran pada bata emisi karbon dioksida dan dapat menghemat biaya pengeluaran dikarenakan tidak membeli kayu bakar untuk proses pembakaran.

4. Pengurangan biaya produksi menjadikan pengurangan harga jual bata dibandingkan dengan bata konvensional dengan nilai pengurangan berkisar Rp. 63,5 per bata.

5. Kualitas mutu bata tanpa bakar berdasarkan nilai uji tekan masih dalam standar mutu SNI dan ASTM, yaitu berkisar $42,70-52,73 \mathrm{~kg} / \mathrm{cm}^{2}$

\section{DAFTAR PUSTAKA}

Austin George T. 1996a. Industri Proses Kimia. Jakarta : Erlangga.

Subaer. 2007. Pengantar Fisika Geopolimer. Makasar : Direktorat Jenderal Pendidikan Tinggi

Sudarsana I Ketut, Made Budiwati Ida Ayu dan Angga Wijaya Yohanes.2011. Karakteristik Batu Bata Tanpa Pembakaran Terbuat Dari Abu Sekam
Padi Dan Serbuk Batu Tabas. Denpasar : Jurnal ilmiah Teknik Sipil.

Laksomono Joddy Arya. Pemanfaatan Abu sekam Padi Sebagai Bahan Baku Silika. Serpong. Pusat Penelitian Kimia.

Herina Silvia. 2005. Kajian Pemanfaatan Abu Sekam Padi Untuk Stabilisasi Tanah Dalam Sistem Pondasi di Tanah Ekspansif. Bandung. Pusat Penelitian dan Pengembangan Permukiman.

http://digilib.its.ac.id/google diakses pada hari kamis 15 September 2011 